\title{
Facts of Packaging Materials and Storage Environment on Post Harvest Quality of Papaya (Carica Papaya L.)
}

\author{
Tizazu Adissie Geletaw Kebede \\ College of Agriculture, Department of horticulture,Wolaita Sodo University, \\ P.O.BOX : 138, Wolaita Sodo, Ethiopia
}

\begin{abstract}
Papaya is a fruit with considerable economic potential in the tropics as there are domestic markets in producing tropical countries and export markets in the sub-tropical and temperate countries In Ethiopia, large quantity of papaya is wasted before it reach the target markets. Because papaya is naturally sensitive to postharvest injuries and mechanical damages due to its thin skin and climacteric type ripening nature. The use of modified atmosphere in combination with cool storage can successfully extend the storage life of papaya fruit. The high density polyethylene packaged fruits characterized by lower weight loss at ambient and evaporative cooler storage compared to the loss in non-packaged fruits stored at ambient condition, low density polyethylene bags maintained better weight compared to newspaper and banana leaf packaging materials. Packaged fruits had more number of marketable fruits than the non-packaged under both ambient and evaporative cooler conditions. The packaging materials of high density polyethylene bags and Low density polyethylene combined with evaporative cool storages have significant effect on maintain shelf life and postharvest quality of papaya compared with banana and news paper packaging materials. But the banana leaves and news paper packaging materials combined with evaporative cool storages also has good effect on maintaining shelf life and postharvest quality of papaya as compared with other packaging materials.
\end{abstract}

DOI: $10.7176 / \mathrm{JBAH} / 10-1-03$

Publication date: January $31^{\text {st }} 2020$

\section{INTRODUCTION}

The papaya, (Carica papaya L.), is a member of the family Caricaceae. It is believed to be native to southern Mexico, Guatemala, and Costa Rica (Teixeira da Silva et al., 2007). The plant can be monoecious, diocious or hermaphrodite. Papaya is cultivated for its fruits, consumed both fresh and as a processed product worldwide (Chonhenchob and Singh, 2005). Papaya is a fruit with considerable economic potential in the tropics as there are domestic markets in producing tropical countries and export markets in the sub tropical and temperate countries. A variety of products such as jam, jelly, nectars, icecream sherbet, yougurt, fruit leather and dried slices may also be made from the ripe fruit. Unripe papaya makes a good concoction of vegetable stew, salad or pickle. The milky latex of the unripe fruit, leaves and other parts of the plant contains papain, a proteolytic enzyme that digests proteins. Papain is used as a meat tenderizer and for medical and industrial purposes (Sankat and Maharaj, 2001).

Postharvest losses generally are categorized into those that occur during storage, during transport, or at the wholesale, retail, or consumer level. Marketing of fruits and vegetables in Ethiopia is complicated by high postharvest losses which are estimated to be as high as 25-35\% (Tadesse, 1991). It has also been estimated by the FAO (2005a) that the postharvest loss of perishable commodities in Ethiopia is as high as 50\%. This high loss has been attributed to several factors among which lack of packaging and storage facilities and poor means of transportation are the major ones (Kebede, 1991; Wolde, 1991). The postharvest losses could discourage farmers from producing and marketing fresh produce and limit the urban consumption of fresh fruits and vegetables. Hence, development of postharvest technologies is believed to make great contribution to improve quality and use of these crops.

Reduction of the losses in a systematic way requires knowledge of postharvest physiology, its applied technical aspect, handling and the appreciation of its biological limitation represented as storage potential (Nakasone and Paull, 1999). Packaging and handling systems have been developed in many countries to move products from farm to consumer expeditiously in order to minimize quality degradation. Procedures include lowering temperature to slow respiration and senescence, maintaining optimal relative humidity to reduce water loss without accelerating decay, adding chemical preservatives to reduce physiological and microbial losses, and maintaining an optimal gaseous environment to slow respiration and senescence (Wills et al., 1989; Desi and Wagh, 1995).Packaging fruits is one of the most commonly used postharvest practice that puts them into unitized volumes which are easy to handle while also protecting them from hazards of transportation and storage (Burdon, 2001). Modified atmosphere packaging for storage and transportation of fruits and vegetables is commonly achieved by packing them in plastic films. Storage in plastic films with different kinds of combinations of materials, perforation and inclusions of chemicals and individual seal packaging are types of modified atmosphere storage (Burdon, 2001; Irtwange, 2006). 
Losses of papaya along the marketing chain can be ascribed to a number of specific causes. As with other fruit losses in handling chains, these loss causes are normally due to parasitic diseases,Physiological disorders, mechanical damage, and overripe fruit (Ceponis and Butterfield 1981). In addition, quality losses can be a problem due to changes in appearance, texture, and flavor (Kader 1983). It is very susceptible to mechanical damage, pest attack and diseases. The fruit has, however, limited shelf life of less than a week under ambient tropical conditions $\left(30^{\circ} \mathrm{C}\right)$ (Sankat and Maharaj, 2001). However, inadequate attention is paid by many producers to the method of harvesting, stage of maturity at harvest, use of fungicidal treatments (both pre- and postharvest), proper packaging and storage methods (Sankat and Maharaj, 2001).

One of the major causes of papayas being rejected at local and export markets is mechanical injuries. The damage can be reduced if the fruits are properly packaged and handled. In Ethiopia Papaya fruits are produced mainly for local markets while some percentage is exported to neighboring countries such as Djibouti and Somaliland. According to Emana and Gebremedhin (2007), considerable quantity of papaya is wasted before it reach the target markets due to limited shelf life of the fruit and poor postharvest handling in Ethiopia.

1.1. Objective

General Object;

To review effect of packaging materials and storage environment on postharvest quality of papaya.

Specific Object : To an overview effect of packaging materials on post harvest quality of papaya

To an overview impact of storage environment on postharvest quality of papaya.

\section{LITERATURE REVIEW}

\subsection{Importance of papaya}

Fruit and seed extracts have pronounced bactericidal activity. The seeds of unripe fruits are rich in benzyl isothiocyanate, a sulphur containing chemical that has been reported to be an effective germicide and insecticide. Carpaine, an alkaloid found in papaya leaves, has also been used for medicinal purpose (Sankat and Maharaj, 2001). Papaya can be used as a diuretic (the roots and leaves), anthelmintic (the leave and seed) and to treat bilious conditions (the fruit). Parts of the plant are also used to combat dyspepsia and other digestive disorders and a liquid portion has been used to reduce enlarged tonsils. In addition, the juice is used for warts, cancers, tumors, corns and skin defects while the root is said to help tumors of the uterus. Root infusion is also used for syphilis and the leaf is smoked to relieve asthma attacks. The Japanese believe that eating papaya prevents rheumatism and in Cuba the latex is used for psoriasis, ringworm and the removal of cancerous growth (Dawson, 1998).

Papaya is a very wholesome fruit, and it is an excellent source of vitamin C and A. It is relished for the attractive pulp color, flavor, succulence, and characteristic aroma (Desi and Wagh, 1995). The fruit contains about $85-90 \%$ water, $10-13 \%$ sugar and $0.6 \%$ protein as well as vitamins $\mathrm{A}, \mathrm{B} 1$ and $\mathrm{B} 2$, iron, calcium, and phosphorous. The nutritional value of the fruit depends on the cultivar, ecological factors during the developmental phases of the fruit and the stage of maturity at which it is consumed (Sankat and Maharaj, 2001).

\subsection{Pre-harvest Factors Affecting the Quality of Papaya}

The provision of good quality produce starts with the use of good planting material and the growing of cultivars acceptable to the market (Burdon, 2001). While the postharvest handling system starts with the harvest, preharvest factors can influence the final quality. Postharvest product quality develops during growing of the product and is maintained, not improved, by post-harvest technologies (Hewett, 2006).

The nutritional composition of a fruit at harvest can vary widely depending on cultivar, maturity, climate, soil type, and fertility. For example, the ascorbic acid content of different cultivars may differ by a factor of 2-3 or higher in many fruits and vegetables (Lee and Kader, 2000). Bananas and papayas increase in carotenoid content with maturation and ripeness, but ascorbic acid content can decrease in bananas and increase in papayas during ripening (Lee and Kader, 2000). Also, ascorbic acid levels in fruit are influenced by the availability of light to the crop and to individual fruits. Even within a cultivar, there is large plant-to-plant variation and withinplant variation in nutrient composition for fruit harvested from the same field (Shewfelt, 1990).

\subsubsection{Genetic factors}

Wide variability is shown by the papayas grown in various countries. It is true that the physico-chemical parameters of papaya varieties differed from one another which are supposed to be due to different genetic makeup of the variety and also because of the difference in their total fruit development and ripening period (Selvaraj et al., 1982 and Desai and Wagh, 1995). The authors indicated that Solo cultivars that are known to have desirable characteristics and are the most important commercial varieties have variations in their fruits. Cultivars, such as Kapoho, Sunrise, Sunset and Waimanalo, have different characteristics. Sunrise has red flesh color while others are yellow. Of these, Waimanalo was indicated to have higher fruit mass and higher marketable fruit (Nakasone and Paull, 1999; Sankat and Maharaj, 2001).

For cultivation, papaya cultivars with only hermaphrodite trees are generally preferred, because the andro 
monoecious types are heterozygous and their phenotypic form is much affected by environment. Temperature, soil moisture and plant vigor all affect this variability (Desai and Wagh, 1995). In hermaphroditic cultivars, proper selection and self pollination can stabilize characteristics at more rapid rate. Fruits from bisexual plants are usually cylindrical or pyriform with small seed cavity and thick wall of firm flesh which stands handling and shipping well. In contrast, fruits from female flowers are nearly round or oval and thin-walled (Nakasone and Paull, 1999).

\subsubsection{Climatic conditions}

Climatic factors, in particular temperature and light intensity, have great impact on the nutritional quality of fruits and vegetables. Consequently, the location of production and the season in which plants are grown can determine their ascorbic acid, carotene, riboflavin, thiamine, and flavonoid contents (Knee, 2002). In general, the lower the light intensity, the lower the ascorbic acid content of plant tissues; best quality papaya fruit, which is determined largely by sugar content, develops under full sunlight in the final four to five days to full ripeness on the tree (Samson, 1986).

Temperature influences the uptake and metabolism of mineral nutrients by plants, since transpiration rates increase with increasing temperature. Lower temperature (less than $10^{\circ} \mathrm{C}$ ) decreases fruit growth, sweetness, and fruit size of papaya. It also influences flower sex and fruit setting (Desai and Wagh, 1995). For example, stamen carpellody is expressed under cool temperatures, with increasing severity at lower temperatures in the coming 40 days before anthesis. The fruit that develop from this carpellody are severely misshapen and unmarketable (Sankat and Mahraj, 2001). At higher temperatures $\left(>35^{\circ} \mathrm{C}\right)$, there is a tendency of bisexual cultivars to form functional male flowers with poorly developed and non functional female parts. This tendency varies with cultivars and within a cultivar (Nakasone and Paull, 1999). The results by Nunes et al. (2006) indicate that fluctuating and/or high or low temperatures that are often encountered for as little as a few hours during handling operations, may result in a considerable amount of papaya rejected. Papaya responds well to adequate irrigation, which helps rapid fruit development and regular fruit yield. Adequate moisture levels result in normal growth; lower levels shift the plants toward sterility, while higher levels result in production of misshaped carpellodic fruit (Desai and Wagh, 1995; Nakasone and Paull, 1999).

\subsubsection{Cultural practices}

Soil type, mulching, irrigation, and fertilization influence the water and nutrient supply to the plant, which can in turn affect the nutritional quality of the harvested plant part. Over feeding of papaya with nitrogen results in soft fruit (Desai and Wagh, 1995). Papaya fruit diseases generally occur after harvest. The incidence of some of these diseases can be minimized by field sanitation and field application of appropriate fungicides. The use of pesticides and growth regulators does not directly influence fruit composition but may indirectly affect it due to delayed or accelerated fruit maturity (Paull and Armstrong, 1994; Nakasone and Paull, 1999).

Fruit quality and storage behavior are influenced greatly by maturity of fruit at harvest. Immature fruits are more subject to shriveling and mechanical damage and are of inferior flavor quality when ripe. Overripe fruits are likely to become soft and mealy with insipid flavor soon after harvest. Fruits picked either too early or too late are more susceptible to postharvest physiological disorders than fruits picked at the proper maturity.

One of the major problems facing papaya fruit marketing is identification of optimum harvest maturity to ensure adequate fruit ripening to good eating quality. Hawaii specifies a minimum total soluble solid of $11.5 \%$ and fruit showing at least 6\% surface coloration at the blossom end region (Quinta and Paull, 1993). Subjective evaluation based on change in color is usually used in practice to judge maturity. Softness to touch is also used as a ripening index. The change of latex color (from white to watery), is an indication of maturity (Sankat and Maharaj, 2001).

\subsection{Postharvest Physiology of Papaya}

Following harvest, the quality of papaya fruit may be considerably reduced by several factors. Similar to other fruits, shelf life of papaya can be affected by intrinsic factors such as respiration, biological structure, ethylene production and sensitivity, transpiration, compositional changes, developmental processes and physiological breakdown (Proulx et al., 2005; Irtwange, 2006).

\subsection{Postharvest Handling of Papaya}

The quality of the harvested fruits and vegetables depend on the condition of growth as well as physiological and biochemical changes they undergo after harvest. The harvesting of fruit at an appropriate stage is important from postharvest shelf life and quality points of view (Desi and Wagh, 1995). During normal handling procedures such as loading, unloading, air or truck transportation, warehouse storage and retail display, fruit and vegetables are often exposed to inappropriate temperatures either due to difficulties in controlling temperature, absence of refrigerated facilities, or lack of information about the produce characteristics and needs (Paull et al., 1997; Nunes et al., 2006).

Fruits bring to our daily diet variety, flavor and aesthetic appeal while also meeting certain essential 
nutritional requirements. However, appearance, flavor and nutritional value may decline greatly due to the way the fruit are handled after being harvested (Nunes et al., 2006). The rate at which changes occur in harvested fruit may be influenced by a range of environmental conditions, including temperature, humidity and atmospheric composition. All may be manipulated by careful management of the postharvest handling system to obtain the best possible quality and storage life for the produce. All fruits and even different cultivars of the same fruit have highly specific requirements and tolerances to storage environments (Wills et al., 1989; Burdon, 2001).

Papaya fruits are sensitive to poor quality out turns and high postharvest losses if harvesting, treatments and handling techniques are inadequate or inappropriate. From harvest, a shelf-life of four to six days under tropical conditions can be achieved with the correct harvest maturity, disease control measures, handling techniques and storage conditions (Irtwange, 2006).

\subsection{Effect Of Packaging Material}

Packaging of fresh produce is needed not only to provide containment for ease of handling but to preserve post storage product quality during distribution and in certain cases, to add value to the commodity during marketing. Packaging systems are product specific but may benefit quality retention through protection from handling abuse and moisture loss and restriction of metabolism. Packaging provides protection from physical damage during storage, transportation and marketing (Wills et al., 1989; Irtwenge, 2006).

There are variety of packages, and packaging materials available. The earliest packages were mostly constructed of plant materials such as woven leaves, reeds and grass stems (Wills et al., 1989). Quinta and Paull (1993) indicated that foam mesh sleeves, foam padding on the bottom of cartons, or paper wrapping are used to prevent abrasion injury of papaya. Desi and Wagh, (1995) also reported that papaya fruits placed stem end down in a box padded with paper or wood wool prevent bruising. Now a days produce is transported and sold in an enormous way packages constructed of wood, fiber board, jute or plastics, banana leaf and newspaper.

An important supplement to proper temperature and relative humidity management is the use of modified (MA) atmosphere (Irtwange, 2006). When used as supplements to keeping fresh horticultural perishables within their optimum ranges of temperature and relative humidity, MA can serve to extend their postharvest life. Modified atmosphere packaging (MAP) of fresh produce relies on modification of the atmosphere inside the package, achieved by the natural interplay between two processes, the respiration of the product and transfer of gases through the package, which leads to an atmosphere richer in $\mathrm{CO}_{2}$ and poorer in $\mathrm{O}_{2}$. This atmosphere can potentially reduce the respiration rate, ethylene sensitivity and production, decay and oxidation and hence delay ripening and senescence (Kader, 1985; Kader and Rolle, 2004).

A modified atmosphere can be defined as one that is created by altering the normal composition of air to provide an optimum atmosphere for increasing the storage length and quality of produce (Lee et al., 1996). The MAP can be generated by either active or passive systems. In the passive system respiring fruit, over time selfgenerate an atmosphere of elevated $\mathrm{CO}_{2}$ and reduced $\mathrm{O}_{2}$. Passive modified atmosphere is created as a result of the produce respiratory activity; consumption of oxygen $\left(\mathrm{O}_{2}\right)$ and emanation of carbon dioxide $\left(\mathrm{CO}_{2}\right)$, occurring within a sealed plastic package (Irtwange, 2006). If the concentration of the respiration gases around the outside of the crop is changed by surrounding it with the package, this will change the concentrations of the gases inside the crop. Active MAP is the replacement of air in a pack with a single gas or mixture of gases; the proportion of each component is fixed when the mixture is introduced. In the active system, desired end point concentrations of $\mathrm{O}_{2}$ and $\mathrm{CO}_{2}$ are established by flushing the fruit with a desired mixture of gases (Irtwange, 2006).

The principal plastic materials for MAP that can be used with fruits and vegetables include poly butylene, LDPE, HDPE, PP, PVC, polystyrene, ionomer, pliofilm, and polyvinylidine chloride (Schlimme and Rooney, 1994). The permeability of films to gases (including water vapor) varies with the type of material from which they are made, temperature, in some cases humidity, the accumulation and concentration of the gas and the thickness of the material (Lee et al., 1996; Thompson, 2001).

Past work has shown that the use of MAP in combination with cool storage can successfully extend the storage life of papaya fruit for up to 3 weeks (Gonzalez-Aguilar et al., 2003). MAP extends product storage life by essentially modifying the gaseous head space environment around fruit, which in turn controls respiration activity and subsequently slows or delays the ripening or senescence process (Kader et al,. 1989).

A study by Gonzalez et al., (1990) shows that, LDPE and HDPE packaging delayed fruit ripening, reduced weight loss, and did not result in any off flavor in papaya fruits. Wills (1990) also reported that, modified atmosphere packaging in plastic film extended the storage life of papaya. In line with this, Lazan et al., (1990) indicated that plastic film wraps are more effective than waxing in reducing water loss from papaya. The author also noted that, low-density polyethylene retarded the development of peel color and reduced the increased titratable acidity during ripening. Fruit softening is also retarded. Similarly, the work of Rohani and Zaipun (2001) reveals that the storage life of papaya was extended to 4 weeks when stored at $10-12^{\circ} \mathrm{C}$ under modified atmosphere (low-density polyethylene bags) condition. 
The use of polymeric film wraps and waxing of papaya have been successful in retarding color development and water loss before fungal decay becomes the limiting factor ( Paull and Chen, 1989). Fruit waxing reduced weight loss of papaya by $14-40 \%$, while plastic shrink wraps reduced it by about $90 \%$ (Paull and Chen, 1989).

\subsection{Effect Of Storage Temperature And Relative Humidity}

The function of a fruit or vegetable storage is to provide an environment that will permit produce to be stored as long as possible without deterioration of quality, which is a composition of flavor, texture, moisture content, and other factors associated with edibility. A desirable environment can be obtained by controlling the temperature and composition of the atmosphere (Berard et el., 1990).

According to Zhou et al., (1997), room and forced-air cooling are commonly used for papaya. The optimum temperature for fruit ripening is 20 to $27.5^{\circ} \mathrm{C}$, with fruit taking 10 to 16 days to reach full skin yellowing from the color-break stage (Zhou et al., 1997; Sankat and Mahraj, 2001). Papaya fruits under ambient tropical condition $\left(30^{\circ} \mathrm{C}\right)$ have a maximum storage life of seven days (Sankat and Maharaj, 2001). Temperatures between 10 and $16^{\circ} \mathrm{C}$ have been found to be adequate for storing papayas (Thompson, 2001). However, a range of storage temperatures have been reported for different cultivars kept under refrigeration, usually for fruit harvested at color-break stage of maturity. Papayas at 10 and $15^{\circ} \mathrm{C}$ can be stored for 16 days, while $12^{\circ} \mathrm{C}$ has been recommended as an optimum storage temperature for two weeks (Sankat and Maharaj, 2001). Tilahun and Kebede (2004) also noted the effect of increasing storage relative humidity and reducing the temperature through a cooling process where evaporative cooling reduced the physiological weight loss in papaya compared to fruits stored under ambient conditions. Evaporative cooling is cooling process whereby the air takes in moisture which is cooled while passing through a wet pad or across a wet surface (Thompson et al., 1998; Aleye et al., 2007).

Storage below $10^{\circ} \mathrm{C}$ has been known to cause chilling injury. It is reported by Paull (1993) that fruits become less susceptible to chilling stress as they ripen. Symptoms of chilling injury occur after 14 days at $5^{\circ} \mathrm{C}$ for mature green fruit and 21 days for $60 \%$ yellow fruit. The decrease in susceptibility has been related to the stage of the fruit climacteric. The tolerance of papayas to temperatures below $10^{\circ} \mathrm{C}$ varies with the maturity of the fruit and the duration of exposure (Zhou et al., 1997).

High temperatures, low relative humidity and high air velocity increase transpiration rates. Hence, these need to be monitored and controlled in storage (Wills et al., 1989; Irtwange, 2006). As a physical process, transpiration can be controlled by applying waxes and plastic films as barriers between the produce and the environment, as well as by manipulating RH, temperature and air circulation (Irtwange, 2006).

The most important method of reducing the rate of water loss from produce primarily involves lowering the capacity of the surrounding air to hold additional water. This can be achieved by lowering the temperature and/or raising the relative humidity by reducing the vapor pressure difference between the produce and air. Water loss can also be effectively reduced by placing an additional physical barrier around the produce, which also reduces air movement across its surface. Simple methods are to pack the produce in to bags, boxes or cartons and to cover stacks with tarpaulins. Materials such as polyethylene film are excellent vapor barriers since their rate of water transfer is low compared with that of paper and fiber board, which have a high permeability to water vapor (Wills et al., 1989).

\subsection{Packaging Materials And Storage Environment On Post Harvest Quality Of Papaya 2.7.1. Weight Loss}

According to Mulualem Azene et al., (2008), the highest weight loss recorded on non packaged papaya fruits stored under ambient conditions (at average temperature $25^{\circ} \mathrm{C}$ and relative humidity $42 \%$ or environments with high temperature and less relative humidity ), whereas the lowest weight loss for papaya fruits packaged with high density polyethylene (HDPE) bags and stored in the evaporative cooler (at temperature $15^{\circ} \mathrm{C}$ and relative humidity $78 \%$ or environment with low temperature and high humidity). In general, weight loss of papaya fruits progressively increased during the storage period both under the evaporative cooler and ambient (AM) storage conditions. The author also indicated the HDPE packaged fruits characterized by lower weight loss at ambient and evaporative cooler storage compared to the loss in non packaged fruits stored at ambient condition , LDPE bags maintained better weight compared to news paper (NP) and banana leaf (BL) packaging materials. Fruits packaged with news paper (NP) and banana leaf (BL) and stored at ambient conditions, a relatively higher weight loss next to unpackaged ones 
Table -1 The interaction effect of packaging materials and storage environment on the percentage weight loss $(\%)$ of papaya fruit during 21 days of storage period

\begin{tabular}{|c|c|c|c|c|c|c|c|}
\hline \multirow[t]{2}{*}{ Treatment } & \multicolumn{7}{|c|}{ STORAGE PERIODS(DAYS) } \\
\hline & 3 & 6 & 9 & 12 & 15 & 18 & 21 \\
\hline HDPE & 0.51 & 0.81 & 1.85 & 3.98 & 6.04 & 9.14 & 11.48 \\
\hline LDOE & 0.71 & 1.06 & 2.78 & 4.56 & 7.57 & 9.66 & 12.76 \\
\hline News paper & 1.68 & 2.65 & 3.9 & 6.44 & 9.23 & 13.33 & - \\
\hline Papaya leaf & 1.13 & 1.63 & 3.62 & 5.33 & 8.85 & 12.52 & - \\
\hline Control & 1.27 & 2.03 & 4.36 & 7.66 & 11.35 & 14.61 & - \\
\hline \multicolumn{8}{|c|}{ Ambient condition } \\
\hline HDPE & 0.76 & 1.82 & 5.34 & - & - & - & - \\
\hline LDPE & 0.96 & 2.08 & 6.15 & - & - & - & - \\
\hline News paper & 2.39 & 4.45 & 11.16 & - & - & - & - \\
\hline Papaya leaf & 2.59 & 5.77 & 14.73 & - & - & - & - \\
\hline Control & 3.46 & 8.40 & 18.32 & - & - & - & - \\
\hline $\mathrm{CV}(\%)$ & 4.39 & 2.81 & 9.65 & 12.82 & 7.18 & 4.4 & 8.37 \\
\hline
\end{tabular}

Highly significant $(P \leq 0.001)$ difference in weight loss of papaya fruits was observed due to the interaction effect of packaging and storage environment during most part of the storage period (Table 1). The weight loss values varied between 0.5 to $14.6 \%$ in the evaporative cooler and from $0.76 \%$ to $18.3 \%$ under ambient condition. The highest weight loss was recorded for control (non packaged) papaya fruits stored under ambient conditions, whereas the lowest was for fruits packaged with high density polyethylene (HDPE) bags and stored in the evaporative cooler.

The weight loss differences among the treatments in this study appear to be due to differences in temperature and relative humidity among the storage environments. Hence, reduced rate of respiration and transpiration at lower temperature and higher relative $(\mathrm{RH})$ humidity could be the reason for such a reduced rate of weight loss of fruits in the evaporative cooler storage (Lam

\subsubsection{Marketability}

Papayas stored in the evaporative cooler remained fresh and firm, looked shiny and had attractive color compared to those stored at ambient conditions. This might be attributed to reduced rate of respiration and transpiration of fruits due to relatively lower temperature and higher RH inside the evaporative cooler. Since a higher rate of respiration decreases shelf life (Lee et al., 1995), the use of low temperature is indicated to be the most important means of extending the storage life of postharvest produce (Exama, 1993). Generally, the percentage marketability of papayas stored in the evaporative cooler higher than those stored under ambient condition.

Packaged fruits had more number of marketable fruits than the non-packaged under both ambient and evaporative cooler conditions. LDPE film packaging had more percent marketable fruits than HDPE, Banana leaf and newspaper package treatments while the unpackaged fruits have the lowest percentage marketability during the storage period. Also, banana leaf and news paper packaging had more number of marketable fruits compared to the unpackaged fruits (Mulualem, Azene et al., 2008). These beneficial effects can be explained by the modified atmosphere created inside the package as well as the reduction in water loss (González, 2003).

Table-2 The interaction effect of packaging materials and storage environment on the marketability (\%) of papaya fruit during 21 days of storage period

\begin{tabular}{|c|c|c|c|c|c|c|c|c|}
\hline \multirow[t]{2}{*}{ Treatment } & \multicolumn{8}{|c|}{ Storage periods(days) } \\
\hline & 3 & 6 & 9 & 12 & & 15 & 18 & 21 \\
\hline \multicolumn{9}{|l|}{ Evaporative cooler } \\
\hline High density polyethyne & 100 & 100 & 94.4 & 87.3 & & 68.5 & 48.9 & 25 \\
\hline Low densiy polyethyne & 100 & 100 & 94.4 & 87.3 & & 70.4 & 53.3 & 29.2 \\
\hline News paper & 100 & 95.1 & 84.7 & 72.8 & & 51.9 & 22.2 & - \\
\hline Papaya leaf & 100 & 93.8 & 83.3 & 74.5 & & 50 & 22 & - \\
\hline Control & 100 & 87.7 & 76.4 & 63.5 & & 40.7 & 20 & - \\
\hline \multicolumn{9}{|l|}{ Ambient } \\
\hline High density polyethylene & 100 & 74.07 & 51.39 & - & - & - & & - \\
\hline Low density polyethyne & 100 & 79.01 & 54.17 & - & - & - & & - \\
\hline News paper & 98.7 & 67.9 & 37.5 & - & - & - & & - \\
\hline Papaya leaf & 97.3 & 65.43 & 36.11 & - & - & - & & - \\
\hline Control & 94 & 58.03 & 26.34 & - & - & - & & - \\
\hline $\mathrm{CV}(\%)$ & 1.2 & 2.2 & 2.5 & 3.9 & 3.4 & 8 . & & 18.8 \\
\hline
\end{tabular}

Packaging and storage conditions had significant $(P \leq 0.01)$ interaction effect on the percentage 
marketability of papaya fruits (Table 2 ). The percentage marketability of papaya fruits decreased from $100.0 \%$ to about $25.0 \%$ in the evaporative cooler after 21 days of storage while under ambient conditions after 9 days of storage all fruits were unmarketable.

lower respiration and ethylene production rates, reduced ethylene action, delayed ripening and senescence, retarding the growth of decay causing pathogens and insects due to modification of the gas atmosphere inside inside the package could be possible reason to extend the storage life of fruits (Exma, 1993; Kader and Rolle, 200).

\subsection{3. firmness}

Generally, there are softening of papayas fruits as the storage time progressed which could be due to texture modification through degradation of polysaccharides such as pectins, cellulose and hemicelluloses that take place during ripening (Irtwange, 2006). It has been well established that texture changes in fruits are consequences of modifications by component polysaccharides that, in turn, give rise to disassembly of primary cell wall and middle lamella structures due to enzyme activity on carbohydrate polymers (Manrique and Lajolo, 2004). Hence, the differences in decrease of firmness of papaya fruits in the different treatments could partly be explained by differences in rate of respiration that affect solubility and depolimerization of pectins during ripening (Lazan et al., 1995).

Mulualem Azene et al., (2008), reported that Both HDPE and LDPE bags maintained firmness of papaya better than banana leaf and news paper packaging materials. Similar findings for papaya also reported by Lazan et al., (1993). The newspaper and papaya leaf package also maintained firmness of papaya fruits better than the unpackaged fruits. These effects of packaging materials may be attributed to their retardation effects of ripening and reduction of water loss (Yamashital et al., 2002; Manrique and Lajolo, 2004).

Mulualem Azene et al., (2008), also indicated that the storage environment affected firmness of papaya fruits. Fruits stored in evaporative cooler firmer, while those stored in ambient condition less firm. In papaya, the rapid loss in firmness during ripening at ambient $\left(25^{\circ} \mathrm{C}\right)$ temperature was associated closely with increase in activity of PG, PME and B-galactosidase as well as depolimerisation of cell wall pectins. Modified atmosphere packaging and moderately low temperature treatments delayed as well as retarded firmness decrease, with the former being more effective than the later in retarding texture change particularly when the fruit was stored at the lower than ambient $\left(15^{\circ} \mathrm{C}\right)$ temperature (Lazan et al.,1993). In similar way, Lazan et al., (1990) noted that fruit softening was retarded in papaya fruit packed with polyethylene film.

Table-3 Effect of packaging materials and storage environment on the firmness $\left(\mathrm{kg} \mathrm{cm}^{-2}\right)$ of papaya fruit during 9 days of storage period

\begin{tabular}{|l|l|l|l|}
\hline \multirow{2}{*}{ TREATMENT } & \multicolumn{2}{l}{ STORAGE PERIODS(DAYS) } & \multicolumn{2}{l|}{} \\
\cline { 2 - 4 } & 3 & 6 & \\
\hline Evaporative cooler & & 3.5 & 1.4 \\
\hline High density polyethylene & 9 & 3 & 1.2 \\
\hline Loe density polyethylene & 8.1 & 2.6 & - \\
\hline News paper & 6.4 & 2.2 & - \\
\hline Papaya leaf & 6.4 & 1.7 & - \\
\hline Control & 5.9 & 0.1 & 0.1 \\
\hline SE & 0.2 & 0.3 & NS \\
\hline LSD(\%) & 0.6 & & \\
\hline Ambient & & 3.1 & 1.3 \\
\hline Evaporative cooler & 7.9 & 2.1 & - \\
\hline Ambient & 6.5 & 0.1 & 0.1 \\
\hline SE & 0.1 & 0.2 & - \\
\hline LSD(5\%) & 0.4 & 8.7 & 9.2 \\
\hline CV(\%) & 6.94 & \\
\hline
\end{tabular}

Packaging had highly significant $(P \leq 0.001)$ effect on firmness of papaya fruits during storage except on day 9. Firmness of papaya fruits during the storage period varied between 1.2 to $9.0 \mathrm{~kg} \mathrm{~cm}^{-2}$ (Table $\underline{3}$ ). All fruits lost their firmness and became soft after 9 days of storage. On day 3, fruits packaged with HDPE and LDPE bags were relatively firmer than those packaged with newspaper, banana leaf and the control. The control fruits were the least firm than the packaged fruits, those fruits packaged with News paper and Papaya Leaf were firmer than the control. On the 6th day storage, there was a significant difference in firmness of fruits packaged with the different materials. HDPE bag packaged fruits were the most firm. Similarly, LDPE bags maintained fruits firmness better next to HDPE bag. Fruits packaged with newspaper, banana leaf and the control lost firmness after 6 days. While, polyethylene bag packaged fruits remained relatively firm till 9 days of the storage period in the evaporative cooler.

The relatively higher firmness of fruits in evaporative cooler might be due to the presence of higher relative 
humidity and lower temperature which will retard the respiration and transpiration rate of the fruits. According to Lazan et al. (1993), the rapid loss in firmness of papaya during ripening at ambient $\left(25^{\circ} \mathrm{C}\right)$ temperature Table-4 The interaction effect of packaging materials and storage environment on total soluble solid ( ${ }^{\circ}$ Brix) content of papaya fruit during 21 days of storage period

\begin{tabular}{|c|c|c|c|c|c|c|c|c|}
\hline & \multicolumn{8}{|c|}{ Storage period(days) } \\
\hline Treatment & 3 & 6 & \multicolumn{2}{|c|}{9} & 12 & 15 & 18 & 21 \\
\hline \multicolumn{9}{|c|}{ Evaporative cooler } \\
\hline HDPE & 10 & 10.2 & \multicolumn{2}{|c|}{10.6} & 10.9 & 11.1 & 10.7 & 10.5 \\
\hline LDPE & 10.1 & 10.1 & \multicolumn{2}{|c|}{10.7} & 10.9 & 11.1 & 10.7 & 10.6 \\
\hline News paper & 10.3 & 10.6 & \multicolumn{2}{|c|}{10.7} & 11.5 & 11.1 & 9.8 & - \\
\hline Papaya leaf & 10.2 & 10.5 & \multicolumn{2}{|c|}{10.9} & 11.3 & 10.9 & 9.8 & - \\
\hline Control & 10.4 & 10.8 & \multicolumn{2}{|c|}{11.4} & 11.0 & 9.3 & 8.9 & - \\
\hline \multicolumn{9}{|l|}{ Ambient } \\
\hline HDPE & 10.6 & & & 10.2 & - & - & - & - \\
\hline LDPE & 10.7 & & & 10.1 & - & - & - & - \\
\hline News paper & 10.9 & & & 9.4 & - & - & - & - \\
\hline Papaya leaf & 10.9 & & & 9.6 & - & - & - & - \\
\hline Control & 11.3 & & & 8.3 & - & - & - & - \\
\hline $\mathrm{CV}(\%)$ & 1.779 & & & 1.224 & 0.987 & 1.109 & 1.208 & 0.668 \\
\hline
\end{tabular}

\subsubsection{Total Soluble Solids (TSS)}

The possible atmospheric modification, that is, reduced $\mathrm{O}_{2}$ and increased $\mathrm{CO}_{2}$ created in the package, combined with lower temperature in the evaporative cooler might have delayed ripening of the fruits as a result of reduced respiration rate (Mathooko, 2003).

The changes in total soluble solids (TSS) content of papaya fruits during the 21 days of storage are displayed in Table $\underline{4}$. There was significant $(P \leq 0.001)$ interaction effect of storage environment and packaging materials on the TSS values of fruits which varied between $8.867-11.5^{\circ}$ Brix in the evaporative cooler and from $8.3-12.5^{\circ}$ Brix under ambient conditions. Camara et al. (1993) reported a range of $8-12^{\circ}$ Brix for Solo papayas, which is in agreement with the present result. The values commonly obtained for TSS of papaya ranges from 7.4-19.0 Brix (Wills and Widjanarko 1995; Paull et al. 1997; Wall, 2006; Zaman et al. 2006).

Generally, packaging papaya fruits in polyethylene bags, news paper and banana leaf combined with evaporative cooler storage showed better maintenance of the total soluble content towards the end of storage time with relatively higher total soluble content TSS value for plastic packaged ones. The possible atmospheric modification, that is, reduced $\mathrm{O}_{2}$ and increased $\mathrm{CO}_{2}$ created in the package, combined with lower temperature in the evaporative cooler might have delayed ripening of the fruits as a result of reduced respiration rate (Mathooko 2003). Hence, packaged fruits do not rapidly deplete their soluble solids as those of the control fruits as observed in this study

\subsubsection{PH values}

Under both storage environments, packaged papayas had higher $\mathrm{pH}$ values compared to their respective unpackaged papayas (Mulualem Azene et al., 2008). The pH of papaya pulp ranges from 4.55 to 5.9 (Camara et al., 1993). The lower $\mathrm{pH}$ of fruits under ambient storage conditions could be associated with the production of acids from catabolism of sugar at faster rate under ambient condition than in the evaporative cooler (Tilahun, 2002). High storage temperature leads to faster respiration rate which is responsible for acid production of the fruits (Wills et al., 1989). Hence, lowering the storage temperature can reduce respiration rate and delay senescence of papaya fruits. On the other hand, the higher $\mathrm{pH}$ values of packaged fruits could be explained by the relatively reduced respiration rate in the package than unpackaged fruits. Reduced $\mathrm{O}_{2}$ and increased $\mathrm{CO}_{2}$ which could be created as a result of produce respiration could delay the rate of respiration in the package (Mathooko, 2003). The $\mathrm{pH}$ values of papaya, generally, decreased with ripening of the fruits; however a tendency of increase in the $\mathrm{p}^{\mathrm{H}}$ value observed towards the end of the storage time and this could be attributed to the fact that fruits at the time proceeding the ripening process is going to diminish its predominant malic acid (Selvarage et al., 1982).

\subsubsection{Titratable acidity (TA)}

Mulualem Azene et al., (2008) reported that the interaction between packaging materials and storage environment had significant effect on the titratable acidity of papaya fruits. The TA value varied from $0.3 \%$ to $0.48 \%$ in the evaporative cooler and $0.357 \%$ to $0.537 \%$ under ambient storage conditions respectively. Other authors also reported similar TA values of papaya fruits (Senait et al., 1992; Camara et al., 1993).

Generally, TA of papaya fruits showed a trend of an initial increase followed by a decrease. The findings of Lazan et al., (1989) and Bron and Jacomino (2006) which showed increased TA content of papaya towards ripening and then followed by a decrease which could be due to its use by the cells as a respiration substrate 
(Selvaraj et al., 1982). The lower TA value of polyethylene bag packaged fruits in the evaporative cooler could be explained by the reduced rate of respiration which results in slow production of acids as a result of carbohydrate catabolism (Tilahun, 2002). On the other hand, the higher loss of TA in unpackaged fruits could be due to depletion of organic acids as a result of relatively faster respiration and ripening rate of fruits at ambient storage (Wills et al., 1989). Lazan et al., (1990) indicated that, seal packaging of papaya with polyethylene film reduced the amount of titratable acidity during ripening at 24 to $28^{\circ} \mathrm{C}$. The atmospheric modification created when fruits are packaged with polyethylene bags may delay respiration and as a direct effect, the consumption of respiration substrates such as organic acids and sugars is retarded. Consequently, as the fruit respires, the $\mathrm{O}_{2}$ level could decrease and the $\mathrm{CO}_{2}$ level increases in the bags (Kader, 1995). Under these atmospheric conditions, the respiration rate of the fruit decrease which is helpful since high acidity in fruit has been suggested to contribute in part to the flavor retention of ripened fruit (Bron and Jakomino, 2006).

In general, titratable acidity value of papaya fruits was maintained at relatively lower level in the evaporative cooler than at ambient storage. Evaporative cooler maintained lower temperature and higher relative humidity than ambient storage. Lower TA in fruits at high relative humidity and in the package during earlier periods of storage may be due to reduced rate of acid production from carbohydrates as a result of slow respiration rate (Wills et al., 1989). Furthermore, slow respiration as well as transpiration rate may contribute for higher retention of water in fruits (Mathooko, 2003).

\subsubsection{Total sugar}

The fruits exhibited a slight increase of total sugars towards ripening and decrease afterwards. Similar trend was reported by Gomez et al., (2002). Mulualem Azene et al., (2008) reported that Papaya fruits packaged with HDPE and LDPE bags retained their TS concentration better than those packaged with news paper, banana leaves and unpackaged at later time of storage. The higher TS concentration of packaged fruits may be explained by the beneficial effects of MAP. When fruits are packaged with polyethylene bags, a modified atmosphere is created, where the $\mathrm{O}_{2}$ level decreases and the $\mathrm{CO}_{2}$ level increases in the bags as the fruit ripen (Kader, 1995). Under this atmospheric condition, the consumption of respiratory substrates such as sugars is retarded and fresh fruit can maintain its quality (Chahin et al., 2002)

Table-5 Effect of packaging materials and storage environment on the total sugar content $\left(\mathrm{mg} 100 \mathrm{~g}^{-1}\right)$ of papaya fruit during 21 days of storage period

\begin{tabular}{|l|l|l|l|l|l|l|l|}
\hline TREATMENT & \multicolumn{3}{|l}{ STORAGE PERIODS(DAYS) } & \multicolumn{5}{l|}{$\mid$} \\
\hline EVAPORATIVE COOLER & 3 & 6 & 9 & 12 & 15 & 18 & 21 \\
\hline HIGH DENSITY POLYETHYNE & 11.8 & 12.2 & 13 & 14.1 & 14.9 & 13.5 & 11.9 \\
\hline LOW DENSITY POLYETHYNE & 12 & 13 & 13.7 & 14.3 & 14.6 & 14.3 & 12.6 \\
\hline NEWS PAPER & 12.4 & 13.1 & 14.3 & 15 & 12.6 & 12 & - \\
\hline Papaya leaf & 12.1 & 13.3 & 14.2 & 15 & 13.8 & 11 & - \\
\hline CONTROL & 12.6 & 13.8 & 15 & 13 & 12.3 & 11.8 & - \\
\hline aMBIENT & & & & & & & \\
\hline EVAPORATIVE COOLER & 11.4 & 12.6 & 15.1 & 14.3 & 13.6 & 12.5 & 12.2 \\
\hline AMBIENT & 13 & 13.6 & 13 & - & - & - & - \\
\hline cv(\%) & 6.223 & 3.747 & 5.204 & 5.025 & 5.966 & 6.02 & 3.655 \\
\hline
\end{tabular}

Higher temperature favors faster utilization of sugars as substrate in the respiration process (Willey, 1994). Whereas the relatively lower temperature in the evaporative cooler helped to preserve the TS of the fruits possibly through retarding respiration and thus delaying ripening (Wang, 1989).

\section{SUMMARY AND CONCLUSION}

Papaya is the most economically important fruit in the caricaceae family which is native to tropical America and is now cultivated in every tropical and subtropical countries. Postharvest losses of fruits and vegetables are high and concerned issue which reach nearly half of production. This high loss has been attributed to several factors among which lack of packaging and storage facilities and poor means of transportation are the major ones. Packaging fruits is one of the most commonly used postharvest practice that puts them into unitized volumes which are easy to handle while also protecting them from hazards of transportation, storage and postharvest loss of quality. Papaya fruits are sensitive to poor quality out turns and high postharvest losses if harvesting, treatments and handling techniques are inadequate or inappropriate. There are variety of packaging material available to reduce post harvest quality loss of papaya, among that a modified atmosphere packaging is altering the normal composition of air to provide an optimum atmosphere for increasing the storage length and quality of produce of papayas. The use of modified atmospheric pressure in combination with cool storage can successfully extend the storage life and post harvest quality of papaya fruits by supplement of proper temperature and relative humidity to fruits and by modification of the atmosphere inside the package, achieved by the natural interplay between two processes, the respiration of the product and transfer of gases through the package, which leads to 
an atmosphere richer in $\mathrm{CO}_{2}$ and poorer in $\mathrm{O}_{2}$. The packaging materials like High Density Polyethylene, Low Density Polyethylene, banana leaves and newspaper combined with storage environments of evaporative cooler and ambient condition storage have played significant role on shelf life and postharvest qualities such as post harvest, total soluble solid, firmness, weight Loss, total sugar and titratable acidity of papaya fruits compared with non packaged one. Therefore use proper packaging material with proper storage environment reduce post harvest quality loss and prolong shelf life of the papaya fruits.

In general, the quality of vegetables and fruits cannot be improved after harvest, and deterioration usually starts after the crop is picked. Similarly large quantity of papaya is wasted in Ethiopia before it reach the target markets started from farmers field due short shelf life and its naturally sensitive to postharvest injuries and mechanical damages due to its thin skin. Therefore in order to reduce post harvest quality or losses of papaya.

\section{REFERENCES}

Aleye Tefera, Tilahun Seyoum and Kebede Woldetsadik, 2007. Effect of disinfection, packaging, and storage environment on the shelf life of mango. Bio. Engin. 96: 1537-1550.

Bron, H.V. and A.P. Jacomino, 2006. Ripening and quality of Golden papaya fruit harvested at different maturity stages. Braz. J. Plant Physiol. 18: 389-396.

Burdon, J.N., 2001. Postharvest handling of tropical and subtropical fruit for export. pp. 1- 19. In: S. Mitra (ed.). Postharvest physiology and storage of tropical and subtropical fruits. Faculity of Horticulture, CAB International, West Bengal, India.

Camara, M.M., C. Diez and M.E. Torija, 1993. Changes during ripening of papaya fruit in different storage systems. Food Chem. 46: 81-84.

Chachin, K., Y. Unda, Y. Imahori and C.Y. Wang, 2002. The effects of modified atmosphere packaging (MAP) on the storage life of loquat fruit (Eriobotrya japonica L. cv. Mogi). Postharv. Biol. Technol. 24: 341-348.

Chen, N.M. and R.E. Paull, 1986. Dvelopment and prevention of chilling injury in papaya fruit. J. Amer. Soc. Hort. Sci. 111: 639-643.

Chonhenchob, V. and S.P. Singh, 2005. Packaging performance comparison for distribution and export of papaya fruit. Packag. Technol. Sci. 18: 125-131.

Dawson, E., 1998. The medicinal properties of the papaya, Carica papaya L., Ethnobotanical Leaflets, Southern Illinois University, Carbondale, $3 \mathrm{p}$.

Desi, U.T. and A.N. Wagh, 1995. Papaya. pp. 4-314. In: D.J. Salunke and S.S. Kadam (eds.). Hand book of fruit science and techenology: Production, composition, storage, and processing. Marcel Dekker, Ink., New York.

Emana, B. and H. Gebremedhin, 2007. Constraints and opportunities of horticulture production and marketing in Eastern Ethiopia, DCG Report No. 46.

Exama, A., J. Arul, R. Lencki and Z. Li, 1993. Suitability of various plastic films for modified atmosphere packaging of fruits and vegetables: Gas transfer properties and effect of temperature fluctuation. Physiological Basis of Postharvest Technologies, Acta Hort. 343: 175-180.

FAO., 2005b. Production status. Food and Agriculture Organizations of the United Nations, http://www faostat.fao.org. assessed on 22/06/2007.

Farber, J.N., L.J. Harris, M.E. Parish, L.R. Beuchat, T.V. Suslow, J.R. Gorny, E.H. Garrett and F.F. Busta, 2003. Microbiological safety of controlled and modified atmosphere packaging of fresh and fresh-cut produce. Comp. Rev. Food Sci. Food safety, 2: 142-160.

Flath, R.A., D.M. Light, E.B. Jang, T.R. Mon and J.O. John, 1990. Head space examination of volatile emissions from ripening papaya (Carica papaya L. Solo variety). J. Agric. Food Chem. 38:1060-1065.

Gonzalez, G., E.M. Yahia and I. Higuera, 1990. Modified atmosphere packaging (MAP) of Mango and Avocado fruit. Acta Hort. 269: 1.

González, G.A., J.G. Buta and C.Y. Wang, 2003. Methyl jasmonate and modified atmosphere packaging (MAP) reduce decay and maintain postharvest quality of papaya 'Sunrise'. Postharv. Biol. Technol. 28:361-370.

Hewett, E.W., 2006. An overview of preharvest factors influencing postharvest quality of horticultural products. Int. J. Postharv. Technol. Innovation, 1.

Irtwange, S.V., 2006. Application of modified atmosphere packaging and related technology in postharvest handling of fresh fruits and vegetables. Agric. Engin. International 4:1-12.

Kader, A.A., 1985. Modified atmospheres and low-pessure systems during transport and storage. pp. 58-63. In: A.A. Kader, R.F. Kasmire, F.G. Mitchell, M.S. Reid, W.F. Sommer, and J.F. Thompson (eds.). Postharvest technology of horticultural crops. University of California Division of Agriculture and Natural Resource, Davis, CA.

Kebede, E., 1991. Processing of horticultural produce in Ethiopia. Acta Hort. 270-301.

Kader, A.A., 1995. Regulation of fruit physiology by controlled/modified atmospheres. Acta Hort. 398: 59-70.

Kader, A.A., 2002. Postharvest technology of horticultural crops. Davis: University of California, Oakland, 
$535 \mathrm{p}$.

Kader, A.A. and R.S. Rolle, 2004. The role of postharvest management in assuring the quality and safety of horticultural produce. FAO Agricultural Support Systems Division, 152: 1010-1365.

Kader, A.A., 2006. Papaya: Recommendations for maintaining postharvest quality. Postharvest Technology Research Information Center. Department of Plant Sciences, University of California, 3p.

Lam, P.F., 1990. Respiration rate, ethylene production and skin color change of papaya at different temperatures. Acta Hort. 269:257-266.

Lazan, H., Z.M. Ali, K.M. Liang and K.L. Yee, 1989. Polygalacturonase activity and variation in ripening of papaya fruit with tissue depth and heat treatment. Physiol. Plant, 77: 93-98.

Lazan, H., Z.M. Ali, and W.C. Sim, 1990. Retardation of ripening and development of water stress in papaya fruit seal-packaged with polyethylene film. Acta. Hort. 269:345-358.

Lazan, H., Z.M. Ali, and M.K. Selamat, 1993. The underlying biochemistry of the effect of modified atmosphere and storage temperature on firmness decrease in papaya. Acta. Hort. 343:141-147.

Lazan, H., M. Kasim and Z.M. Ali, 1995. $\beta$-Galactosidase, polygalacturonase and pectin esterase in differential softening and cell wall modification during papaya fruit ripening.

Plant Physiol. 95: 106-112.

Lee, L., J. Arul, R. Lencki, and F. Castaigne, 1995. A review on modified atmosphere packaging and preservation of fresh fruits and vegetables. Physiological basis and practical aspects, Part-1, Pack. Technol. Sci. 8: 315-331.

Lee, L., J. Arul, R. Lencki, and F. Castaigne, 1996. A review on modified atmosphere packaging and preservation of fresh fruits and vegetables. Physiological basis and practical aspects, Part-2, Pack. Technol. Sci. 9: 1-17.

Lee, S.K. and A.A. Kader, 2000. Preharvest and postharvest factors influencing vitamin C content of horticultural crops. Postharv. Biol.Technol. 20: 207-220.

Lichanporn, I. and S. Kanlavanarat, 2006. Effect of organic acid and modified atmosphere conditions on quality of shredded green papaya (Carica papaya L.). Acta Hort. 712: 729-34.

Maharaj, R. and C.K. Sankat, 1989. Waxing and plastic wraps influence water loss from papaya fruit during storage and ripening. Postharv. Technol. 20: 207-220.

Manrique, G.D. and F.M. Lajolo, 2004. Cell-wall polysaccharide modifications during postharvest ripening of papaya fruit (Carica papaya). J. Postharv. Biol. 1000-1016.

Mathooko, F.M., 2003. A Comparison of modified atmosphere packaging under ambient conditions and low temperatures storage on quality of tomato fruit. African J. Food Agric. Nutrition Develop. 3.

Maul, F., S.A. Sergeant, E.A. Sims, E.A. Baldwin, M.O. Balaban and O.J. Huber, 2000. Tomato flavor and aroma quality as affected by storage temperature. J. Food Sci. 65: 1229-1237.

Mulualem, Azene, Tilahun Seyoum Workneh \& Kebede Woldetsadik, 2008. Effect of packaging materials and storage environment on postharvest quality of papaya fruit. J. Food Sci Technol (June 2014) 51(6):10411055

Nakasone, H.Y. and R.E. Paull, 1999. Tropical fruits. CABI Publishing, Wallingford, UK. 45p.

Paull, R.E. and N.J. Chen. 1989. Waxing and plastic wraps influence water loss from papaya fruit during storage and ripening. J. Amer. Soc. Hort. Sci . 114:937-942.

Paull, R.E., 1993. Pineaple and papaya. pp. 291-311. In: G.B. Symour, J.E. Taylor and G.A. Tucker (eds.). Biochemistry of fruit ripening. Chapman and Hall, New York, Tokyo.

Paull, R.E. and N.J. Chen. 1997. Minimal processing of papaya (Carica papaya L.) and the physiology of halved fruit. Post harv. Biol. Technol. 12: 93-99.

Paull, R.E., W. Nishijima, R. Marcelino and C. Cavaletto, 1997. Postharvest handling and losses during marketing of papaya (Carica papaya L.). Postharv. Biol. Technol. 11:165-179.

Paull, R.E., K. Cross and Y. Qiu, 1999. Changes in papaya cell walls during fruit ripening. Postharv. Biol. Technol. 16: 79-89.

Proulx, E., M.C.N. Nunes, J.P. Emond and J.K. Brecht, 2005. Quality attributes limiting papaya postharvest life at chilling and non chilling temperatures. Proc. Fla. State Hort.

Soc. 118:389-395.

Quinta, M.E.G. and R.E. Paull, 1993. Mechanical injury during postharvest handling of 'Solo' papaya fruit. $J$. Amer. Soc. Hort. Sci. 118: 618-622.

Rohani, M.Y. and M.Z. Zaipun, 2001. MA storage and transportation of Eksotika' papaya. Acta Hort. 740: $303-$ 311.

Sankat, C.K. and R. Maharaj, 2001. Postharvest physiology and storage of tropical and subtropical fruits. Faculity of Horticulture, CAB International, West Bengal, India. Papaya. Pp.167-185. in: S. Mitra (ed.).

Schlimme, D.V. and M.L. Rooney, 1994. Packaging of minimally processed fruits and vegetables. In: Willey, R.C.(ed.). Minimally processed refrigerated fruits and vegetables. pp. 135 - 179, New York, Chapman and 
Hall.

Singh, S.P. and D.V.S. Rao, 2005. Effect of modified atmosphere packaging (MAP) on the alleviation of chilling injury and dietary antioxidants levels in Solo papaya during low temperature storage. Europ. J. Hort. Sci. 70: 246-252.

Tadesse, F., 1991. Postharvest losses of fruits and vegetables in horticultural state farms, Acta Hort. 270: 261270.

Teixeira da Silva JA., Rashid Z., Nhut DT, Sivakumar D., Gera A., TexeirabSouza M Jr.,and Tennant PF., 2007. Papaya (Carica papaya L.) biology and biotechnology. Tree and Forestry Science and Biotechnology 1, 4773

Thompson, A.K., 2001. Controlled atmosphere storage of fruits and vegetables. CAB

International, UK, 97p.

Thompson, J.F., F.G. Mitchell, T.R. Runsey, R.F. Kasmire and C.H. Crisosto, 1998. Commercial cooling of fruits vegetables, and flowers, U.S.A., University of California, ANR Publications, 65p.

Tilahun Seyoum, 2002. The improvement of the shelf life of vegetables through pre and postharvest treatment Ph.D. Dissertation presented to the University of Free State. South Africa. 270 p.

Tilahun Seyoum and Kebede Woldetsadik, 2004. Forced ventilation evaporative cooling: A case study on banana, papaya, orange, mandarin, and lemon. Trop. Agric. 81: 1-6.

Wang, C.V., 1989. Chilling injury of fruits and vegetables. Food Revol. International, 5: 209-236.

Wills, R.B.H., W.B. Mc Glasson, D. Graham, T.H. Lee and E.G. Hall, 1989. Postharvest-An introduction to the physiology and handling of fruit and vegtables, 3rd edn., New York, U.S.A., Van Nostrand Reinhold, 46p.

Wills, R.B.H., 1990. Postharvest technology of banana and papaya in Asea. Asean Food J. 5: 47-50.

Wills, R.B.H. and S.B. Widjanarko, 1995. Changes in physiology, composition and sensory characteristics of Australian papaya during ripening. Australian J. Exper. Agric. 35:1173-1176.

Wolde, B., 1991. Horticulture marketing systems in Ethiopia. Acta Hort. 270: 21-31.

Yamashital, F., L.H.S. Miglioranzal, L.A. Miranndall, and C.M.A. Souzalll, 2002. Effects of packaging and temperature on postharvest of Atemoya. Braz. Frutic. 24.

Yeshida, O., H. Nakagaua, N. Ogura and T. Sato, 1984. Effect of heat treatment on the development of polygalacturonase activity in tomato fruit during ripening. Plant Cell Physiol. 25: 500-509.

Zaman, W., S.K. Biswas, M.O.H. Helali, M. Ibrahim and P. Hassan, 2006. Physio-chemical composition of four papaya varities grown at Rajshahi. J. Bio. Sci. 14: 83-86.

Zhou, L., R.E. Paull and N.J. Chen, 1997. Papaya. In: R.E. Paull, W. Nishijima, M. Reyes and C. Cavaletto (eds). A review of postharvest handling and losses during marketing of papaya (Carica papaya L). Department of Tropical Plant and Soil Sciences University of Hawaii at Manoa, Honolulu. 